\title{
MONEDAS HISPANO-MUSULMANAS. Manual de lectura y clasificación. Antonio Medina Gómez.
}

Toledo, 1992, 550 págs.

En 1879, D. Francisco Codera y Zaidín publicó su Manual de Numismática Arábigo-Española, que ha sido durante mucho tiempo el manual donde han aprendido los aficionados y especialistas que han deseado interesarse por el mundo de las monedas andalusíes. En realidad hubo algún intento de sustituir o, mejor dicho, complementar dicho libro como ocurrió con el Prontuario de datos de la moneda arábigo-española, de J. J. Rodriguez Lorente (ed. Vico Madrid 1982). Fuera de nuestras fronteras si se conocen obras más recientes, que continuaban el camino emprendido por Codrington con su A Manual of Musulman Numismatic (Londres 1904), como las obras de R. Plant, Arabic Coins and how to read them (Londres 1973) y R. Broome, A Handbook of Islamic Coins (ed. Seaby, Londres 1985), pero en todas ellas lo andalusí quedaba en franca minoría y a un nivel bastante reducido.

La obra de D. Antonio Medina ha venido a ocupar el vacío que teníamos en este campo; no es el trabajo de un especialista formal o de un académico sino el de una persona muy conocedora del tema que trata, por el que siente un gran cariño y que ha elaborado un instrumento sumamente útil para adentrarse en el estudio de la moneda islámica.

Es evidente que existen problemas, no siendo el menor (reconocido por el autor) que este libro estaba finalizado en los años setenta y y no ha sido publicado, tras diversos intentos, hasta 1992. Este desfase cronológico se aprecia en la bibliografía y en algunas de las consideraciones o introducciones históricas que acompañan a las diferentes secciones. Aún señalando estas lagunas la suma de los aciertos es mayor.

El libro está organizado en un Prefacio, Introducción, Generalidades, I. Provincia del Califato de Damasco, 2 Emirato Independiente, 3. Califato de Córdoba, 4. Reinos de Taifas, 5.Dominación almorávide, 6. Sublevación anti-almorávide, 7. Dominación almohade, 8. Sublevación anti-almohade (Hudíes de Murcia, Nasaríes de Granada). Apéndice (léxico y Bibliografía).

Es decir un recorrido total por la moneda andalusí; lo más importante de esta obra es la originalidad en la presentación de los materiales y las variedades de leyendas. El autor ha optado por una via incomoda y compleja, la de reunir un buena representación fotográfica de las piezas al tiempo que reproduce en escala aumentada la grafía original de cecas, numerales, leyendas principales y sobre todo las secuencias de nombres que aparecen en las diferentes emisiones y reinados. El despiece de fotografías y su combinación con las reconstrucciones epigráficas son muy útiles para familiarizarse con este tipo de leyendas. Es en esta parte del trabajo donde la experiencia y el archivo de D. A. Medina han sido un factor de primera importancia.

Esto puede parecer una perogullada pero lo primero que todo novel ha comprobado al manejar un catálogo (y no dominar el árabe) era la diferencia entre los caracteres de tipografía (usados en obras clásicas como las de Codera ', Vives ${ }^{2}$ o Miles $\left.{ }^{3}\right)$, con la realidad de las monedas. En este aspecto la obra de Medina resulta de una gran utilidad para familiarizar al lector con la auténtica grafía monetal de las leyendas.

En las descripciones de las leyendas y variantes de las mismas suele indicar las referencias a las principales obras de consulta, aunque de una forma muy escueta; sería de agradecer (en mi modesta opinión) que estas referencias se completasen, añadiendo mayor utilidad al libro.

Ciertas piezas sin identificar aparecen aisladas por las páginas a modo de trampa o reto para el lector, algo que creo innecesario, aunque cualquier representación más amplia para prácticas hubiera servido para la misma función.

Por todo ello resulta una obra de manejo ejemplar, sumamente didáctica para quienes desean aprender a desenvolverse en el mundo de la numismática andalusí; a veces desde la experiencia de la docencia universitaria es facil criticar ciertos trabajos externos pero en este caso, y desde la misma perspectiva, solo puedo decir que he utilizado esta obra en diferentes seminarios con mis alumnos con resultados muy satisfactorios para ellos, y esto es una de las mejores alabanzas que se le pueden hacer.

Alberto Canto García

I CODERA Y ZAIDÍN, R. ( 1879): Manual de Numismática Arábigo-española, Madrid.

2 VIVES ESCUDERO, A. ( 1893$)$ : Monedas de las dinastías Arábigo-españolas, Madrid.

3 MILES, G.C. (1950): The Coinage of the Ummayads of Spain, Nueva York. 